\title{
Mangled extremity: to salvage or not to salvage?
}

\author{
Kevin Bain, David Parizh, Anthony Kopatsis, Ramamohan Kilaru
}

Department of General Surgery, NYU Lutheran, Brooklyn, New York, USA

\section{Correspondence to} Dr David Parizh, david.parizh@nyumc.org

Accepted 10 December 2016

CrossMark

To cite: Bain $\mathrm{K}$, Parizh $\mathrm{D}$, Kopatsis A, et al. BMJ Case Rep Published online: [please include Day Month Year] doi:10.1136/bcr-2016218359

\section{DESCRIPTION}

A man aged 34 years post jump from the platform onto an incoming train presented as a level I trauma notification with bilateral mangled lower extremities and tourniquets in place (figure 1). Our patient was evaluated in a multidisciplinary fashion, making sure to follow proper ATLS guidelines. On presentation, he was hypotensive, but responded to crystalloid and blood products. Secondary survey revealed pulseless, paralysed extremities that lacked sensation and were grossly contaminated. The Mangled Extremity Severity Score (MESS) calculated as 9. With all factors considered, the patient was emergently taken to the operating theatre for left above knee and right below knee amputations.

The mangled extremity represents complex injury of vasculature, nerve, soft tissue and bone. The management of limb salvage versus amputation remains a controversial topic. Salvage attempts can be associated with prolonged hospitalisations, increased costs, multiple procedures and increased mortality. ${ }^{2}$

Multiple factors have been identified which correlate with the need for amputation of mangled

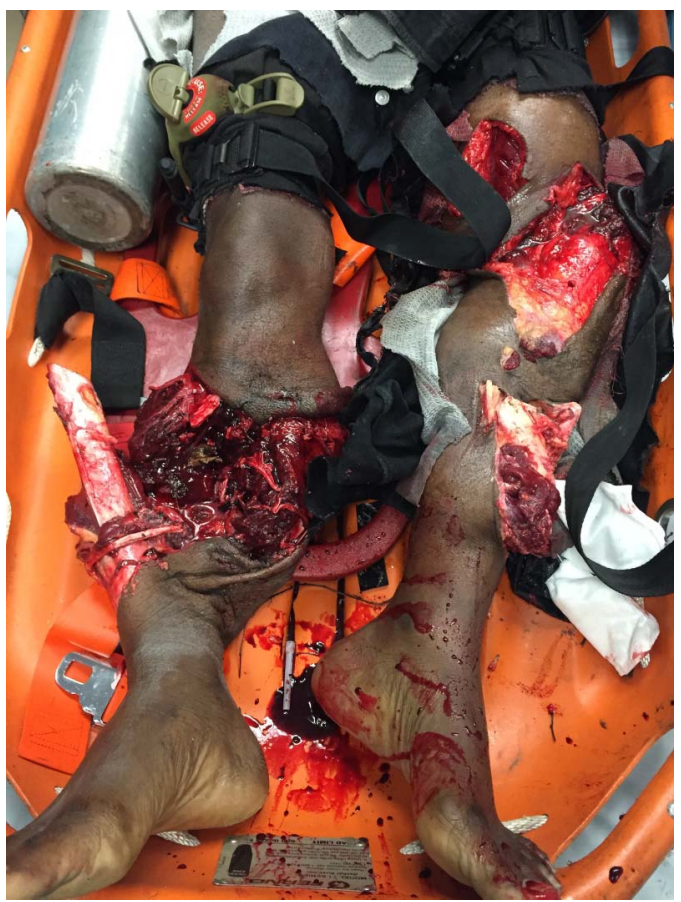

Figure 1 Bilateral mangled lower extremities with a calculated Mangled Extremity Severity Score of 9 in a man aged 34 years who attempted suicide by jumping from a train platform. extremities. Based on objective criteria, scoring systems have been developed to help guide the decision process. The MESS uses four criteria to predict the need for amputation: extent of skeletal/ soft tissue injury, limb ischaemia, shock and patient age. MESS $\geq 7$ is highly predictive of need for amputation. ${ }^{1}$

\section{Learning points}

- The Mangled Extremity Severity Score (MESS) is a scoring system developed for the management of the mangled extremity, with scores $<6$ favouring salvage attempts.

- Approach to the mangled extremity should involve multiple specialties and disciplines. There are numerous scoring systems developed for management of the mangled extremity aside from the MESS. Other scoring systems include the Predictive Salvage Index, Limb Salvage Index, Nerve Injury, Ischaemia, Soft tissue injury, Skeletal injury, Shock and Age of patient score and Gustillo-Anderson score. Studies have compared scoring systems, including MESS, and have failed to prove their validity. ${ }^{3}$

- There is no unanimously accepted scoring system guiding management of the mangled extremity; therefore, a systematic and multidisciplinary approach that encompasses all factors must be employed. ${ }^{13}$

Contributors KB and DP acquired data, analysis and interpretation of data, drafting the article and revising intellectual content. AK and RK are responsible for revising intellectual content, final approval of the version to be published and analysis and interpretation of data.

Competing interests None declared.

Patient consent Obtained.

Provenance and peer review Not commissioned; externally pee reviewed.

\section{REFERENCES}

1 Schirò G, Sessa S, Piccioli A, et al. Primary amputation vs limb salvage in mangled extremity: a systematic review of the current scoring system. BMC Musculoskelet Disord 2015;16:372.

2 Scalea TM, DuBose J, Moore EE, et al. Western Trauma Association critical decisions in trauma: management of the mangled extremity. J Trauma Acute Care Surg 2012;72:86-93.

3 Fodor L, Sobec R, Sita-Alb L, et al. Mangled lower extremity: can we trust the amputation scores? Int J Burns Trauma 2012;2:51-8. 
Copyright 2016 BMJ Publishing Group. All rights reserved. For permission to reuse any of this content visit http://group.bmj.com/group/rights-licensing/permissions.

BMJ Case Report Fellows may re-use this article for personal use and teaching without any further permission.

Become a Fellow of BMJ Case Reports today and you can:

- Submit as many cases as you like

- Enjoy fast sympathetic peer review and rapid publication of accepted articles

- Access all the published articles

Re-use any of the published material for personal use and teaching without further permission

For information on Institutional Fellowships contact consortiasales@bmjgroup.com

Visit casereports.bmj.com for more articles like this and to become a Fellow 